\title{
O Ensino de Língua Portuguesa Através de um Projeto de Letramento: o jornal escolar
}

\author{
Ana Paula da Silva LINO* \\ Andreia da Cunha Malheiros SANTANA**
}

* Mestrado Profissional em Letras pela Universidade Estadual de Londrina. Atualmente é professora da Secretaria Estadual de Educação do Paraná (SEED). Contato: apsilva0608@gmail.com.

** Mestrado (2003) e Doutorado (2010) em Educação Escolar pela Universidade Estadual Paulista Júlio de Mesquita Filho (UNESP). Atualmente, é professora adjunta na Universidade Estadual de Londrina (UEL). Contato: andreiacunha@uel.br.

\begin{abstract}
Resumo:
O presente trabalho tem como objetivo apresentar uma proposta para o ensino de língua portuguesa baseada na perspectiva do letramento. Trata-se de uma pesquisa-ação cujo objetivo específico foi a criação de um jornal escolar como estratégia para promover o ensino de língua portuguesa; a partir deste objetivo foram trabalhados os gêneros discursivos necessários à elaboração do jornal. Para tanto, este trabalho tem como base os documentos oficiais que regem a educação brasileira; os Estudos do Letramento, segundo Kleiman (1995, 2000, 2005 , 2006, 2010), Soares (2001) e Street (2014). Também há a assunção da concepção sócio-histórica da linguagem baseada em Bakhtin (2003), considerando que as práticas sociais devem orientar o ensino da língua materna no contexto escolar. Como resultado, foi possível constatar que pensar no ensino a partir das práticas sociais colabora para o processo de ensino-aprendizagem, uma vez que a produção dos gêneros do jornal (BONINI, 2014), relacionada a questões dos alunos e da comunidade, conferiu maior sentido no momento da produção.
\end{abstract}

\section{Palavras-chave:}

Jornal escolar. Projetos de letramento. Ensino de Língua Portuguesa.

Signum: Estudos da Linguagem, Londrina, v. 21, n. 3, p. 424-447, dez. 2018 


\section{O Ensino de Língua Portuguesa Através de um Projeto de Letramento: o jornal escolar}

Ana Paula da Silva Lino; Andreia da Cunha Malheiros Santana

\section{INTRODUÇão}

A escrita, para além de um processo histórico cultural complexo, tem se tornado, cada vez mais, elemento indispensável nas interações e relações sociais. O crescente processo de urbanização e industrialização do Brasil, a expansão dos meios de comunicação e o impacto da escrita em todas as esferas de atividades humanas têm deflagrado a importância do domínio do uso da linguagem nos mais diversos contextos, para os mais diversos fins. Assim, estratégias que objetivem melhorar e universalizar o ensino brasileiro, tal como associálo às necessidades de interação nas mais variadas práticas sociais, devem se relacionar às demandas dessa nova realidade social e cultural.

Embora, diante de tal cenário, o processo de ensino-aprendizagem da língua materna tenha alcançado lugar de destaque dentro das discussões sobre a tentativa de melhora do ensino no país, muitos alunos, ao finalizarem o ensino básico, ainda estão despreparados para a utilização adequada da leitura e da escrita nas mais diversas situações de interação. Parte desse despreparo está, muitas vezes, relacionado à forma como o trabalho com a linguagem é desenvolvido em sala de aula. Muitas atividades de leitura e escrita na escola, de forma artificial, não atendem às necessidades reais de uso e função da linguagem. Muito do que se faz em relação ao ler e ao escrever tem um fim na própria leitura e na própria escrita. Esse inadequado processo de escolarização acaba desestimulando os alunos que, não raramente, escrevem apenas para cumprir uma obrigação escolar. Diante dessas reflexões, apresentaremos, neste artigo, uma proposta de intervenção pedagógica que busca considerar a escrita e a leitura enquanto prática social, articulando-as para a elaboração de um jornal no ambiente escolar.

A elaboração do jornal partiu de situações reais e pertinentes ao interesse dos alunos, a fim de que estes percebessem a função social da escrita e ultrapassassem a visão tradicional do trabalho com escrita na escola, cujo objetivo maior é "tirar nota". Nessa perspectiva, entende-se a necessidade de aproximar a realidade dos estudantes das atividades de leitura e escrita desenvolvidas na escola, numa tentativa de ressignificar também o espaço escolar. É preciso compreender que a escola em si também é uma microssociedade e que os projetos de letramento podem contribuir para derrubar, mesmo que simbolicamente, os muros que a separam e a isolam como se tudo que acontecesse nela fosse artificial e apenas um treino à realidade. "A introdução da Consciência Linguística Crítica e do letramento como prática 
social crítica pode, acredito, facilitar o processo. Introduzi-los em sala de aula não é um luxo, mas uma necessidade" (STREET, 2014, p. 155).

A pesquisa que deu origem a este artigo pode ser classificada como pesquisa-ação. Para Gil (2010, p. 42), "a pesquisa-ação vem emergindo como uma metodologia para intervenção, desenvolvimento e mudança no âmbito de grupos, organizações e comunidade". Por meio desta pesquisa-ação foi possível focalizar um problema, refletir sobre a ação durante o processo da pesquisa, planejar e replanejar ações; reunir as conclusões e os ganhos para ressignificar a prática pedagógica, especificamente no que se refere ao processo de ensinoaprendizagem. A pesquisa foi desenvolvida por meio de "um projeto de letramento compreendido como modelo didático" (TINOCO, 2008), aplicado em uma turma do $9^{\circ}$ ano do ensino fundamental II, com 30 alunos do período vespertino, em uma escola pública periférica na cidade de Londrina-PR. Vale ressaltar que tal pesquisa foi aprovada pelo Comitê de Ética da Universidade Estadual de Londrina.

O projeto de letramento ocorreu durante o terceiro bimestre do ano letivo de 2017, nos meses de agosto e setembro, em aproximadamente 50 horas-aula, e foi coordenado pela professora regente e também pesquisadora com a colaboração da turma, uma vez que o projeto apoiou-se nas interações dos alunos e de propostas de leitura e escrita a partir das práticas sociais em que eles estão inseridos.

Para melhor apresentação da pesquisa realizada, este artigo está dividido em três partes: na primeira, abordaremos a perspectiva do letramento e sua relação com os estudos linguísticos, visando a construção de projetos que estimulem a aprendizagem dos estudantes; no segundo momento, abordaremos o discurso legal que orienta uma abordagem múltipla da língua e faz referência explícita ao letramento; no terceiro ponto, apresentaremos o projeto do jornal escolar realizado com os alunos e, em seguida, as conclusões.

\section{O Projeto de Letramento e a sua Articulação com a Realidade Escolar}

Segundo Hernández e Ventura (1998), os projetos de trabalho se organizam a partir de uma concepção globalizada em que a articulação entre as diversas áreas do conhecimento e seus conteúdos é estabelecida pela necessidade de resolver problemas emergentes e que possam ser trabalhados em um processo significativo de aprendizagem, de construção e reflexão de conhecimento.

Uma questão fundamental para que um indivíduo possa compreender o mundo é que saiba como ter acesso, analisar e interpretar a informação. $O$ caminho que vai da informação ao conhecimento pode ser realizado por diferentes vias, diversas estratégias, sendo a mais relevante a consciência do indivíduo sobre seu próprio processo como aprendiz.

Tinoco (2008) acrescenta, que independentemente das concepções sobre o trabalho com projetos, há um ponto convergente entre tais abordagens que se situa na recriação do trabalho escolar devido à ressignificação e à recontextualização desses projetos como resultado 
das exigências das diferentes épocas. Se na vida, acrescenta a autora, as ações destinam-se a variados fins, por meio de motivações e agentes sociais variados, na busca de objetivos predefinidos, em sala de aula, entretanto, "as atividades e tarefas desenvolvidas representam ações individuais que, em geral, têm início e fim nelas próprias” (TINOCO, 2008, p. 175). Assim, compreende-se que o trabalho com projetos no espaço escolar deve ser uma opção do professor e dos envolvidos no processo para a busca de uma aprendizagem significativa que tenha reflexos nas ações dos participantes no mundo social, ultrapassando um fim em si mesmo.

Nessa linha, embora os projetos de letramento dialoguem, em seus princípios gerais, com a abordagem do projeto de trabalho de Hernández (1998) e do desenvolvimento de projetos apresentado nos Parâmetros Curriculares Nacionais - PCN (BRASIL, 1998), sua especificidade reside no fato de ter no trabalho com a linguagem seu ponto central. Os projetos de letramento "focalizam a leitura e a escrita a partir de uma ancoragem que permite vislumbrar os usos sociais da escrita na escola e fora dela, bem como o papel sociopolítico da esfera escolar junto a outras instituições sociais" (TINOCO, 2008, p. 175). Tais projetos apresentam uma concepção de linguagem mais próxima às recentes teorias - língua como produto social -, e favorecem as atividades com diversos gêneros discursivos nas várias esferas sociais, além de contribuírem para que os alunos tornem-se efetivamente autores de seus discursos, exercendo papel de protagonistas nas relações sociais permeadas pela escrita e pelas relações de poder que dela emanam.

Para Kleiman (2000, p. 238) um projeto de letramento pode ser definido como

um conjunto de atividades que se origina de um interesse real na vida dos alunos e cuja realização envolve o uso da escrita, isto é, a leitura de textos que, de fato, circulam na sociedade e a produção de textos que serão lidos, em um trabalho coletivo de alunos e professor, cada um segundo sua capacidade.

A autora ainda defende que os projetos de letramento devem ser o eixo estruturador dos conteúdos, ou seja, da prática social para as atividades em sala de aula, passando por uma ressignificação do ensino da língua portuguesa. Em conformidade com essa concepção, Tinoco (2008) também corrobora a ideia de que os projetos de letramento, como modelos didáticos, têm como foco o trabalho com a leitura e a escrita como ferramentas à agência social, garantindo o processo de mudança, autonomia e emancipação ao exercício da cidadania.

Neste sentido, Possenti (1996) afirma que o objetivo da escola é ensinar a língua padrão e criar condições para seu uso efetivo; mas não ensinar simplesmente gramática. Para ele, não se aprende por exercícios, mas por práticas significativas, contextualizadas (p. 47); por isso não há razão para pautar o ensino de língua materna apenas na gramática. As atividades práticas desenvolvidas através do projeto de letramento focado na produção de um jornal escolar fizeram isto. 
Entender um projeto de letramento como modelo didático implica considerar a aprendizagem da escrita para atingir fins relacionados ao agir socialmente e que não seja apenas para a mera aprendizagem formal e metalinguística do sistema da língua. Subjazem ao trabalho com projetos de letramento, como organização de um processo educativo, princípios diferentes dos que regem o modelo tradicional de ensino (TINOCO, 2008).

Para as instituições de ensino que ainda priorizam as atividades analíticas e seguem um modelo tradicional de ensino da língua materna, trabalhar o gênero como elemento estruturante do currículo pode significar apenas um novo objeto para atividades metalinguísticas, descontextualizado e com fim em si mesmo. Já na proposta de trabalho com projetos de letramento, os gêneros são considerados instrumentos para a ação sociopolítica, como um meio de agência (MARQUES, 2016). Dessa maneira, "a diferença nos dois enfoques equivale à diferença existente entre, de um lado, saber conhecer os mapas (conhecimento do gênero) e, de outro, consultar o mapa para ir, de fato, a um lugar (prática social)" (KLEIMAN, 2006, p. 33).

Assim, os projetos de letramento, ao potencializarem o trabalho contextualizado com os gêneros, em atividades que demandam a aplicabilidade destes em situações reais de uso, tornam o processo de ensino-aprendizagem da leitura e da escrita significativo, já que a produção e a leitura desses gêneros têm funções específicas relacionadas às práticas sociais dentro e/ou fora da própria escola.

Nesse sentido, o distanciamento entre as práticas escolares e as práticas sociais de uso efetivo da língua deve ser minimizado. Nessa direção, os projetos de letramento podem configurar-se com uma alternativa para aproximar tais práticas, principalmente na modalidade escrita.

Para Oliveira, Tinoco e Santos (2014, p. 7), os projetos de letramento, compreendidos "como uma ferramenta que favorece uma aprendizagem contextualizada e, por isso, significativa", ampliam as possibilidades de ensino da língua escrita e o professor torna-se um agente de letramento que busca entender quais são as funções da língua escrita para determinados grupos.

Nessa perspectiva, o papel do professor - especificamente de língua materna - e do processo de ensino-aprendizagem da língua portuguesa estão voltados às práticas sociais e culturais dos alunos, os projetos de letramento destacam-se por priorizarem um trabalho pedagógico que articule questões sociais com os conteúdos curriculares, buscando relacionar os conhecimentos com as demandas locais para a agência social.

Tinoco (2008), ao refletir sobre a ressignificação das práticas pedagógicas por meio do trabalho com projetos de letramento, destacando que esse modelo didático "pressupõe o trabalho com demandas de leitura escrita do mundo social" (p. 217), propõe um quadro ilustrativo de aspectos e princípios recorrentes em tais projetos

Brian Street (2014), ao estudar o modelo de letramento escolar, identificou o modelo autônomo e o modelo ideológico de letramento. O modelo autônomo de letramento, para 
Street (2014), de caráter etnocêntrico e hierárquico, estaria centrado apenas no domínio do código, da tecnologia da escrita, de forma supostamente neutra e objetiva, homogênea, separada das relações culturais. O letramento autônomo representa um modelo único de letramento, isento, singular, técnico e centrado nas relações hegemônicas.

Essa concepção - muitas vezes implícita nas ações escolares - considera que só há uma forma de letramento e que o aluno deve se adaptar a esse modelo. Nesse sentido, é preciso entender que "o fato de uma forma cultural ser dominante é, no mais das vezes, disfarçado por trás de discursos públicos de neutralidade e tecnologia nos quais o letramento dominante é apresentado como o único letramento" (STREET; BAGNO, 2006, p. 472). Logo, ao ignorar e ao desconsiderar as experiências que os alunos trazem do cotidiano e as formas de linguagem que realmente utilizam para agir socialmente, a escola tem mais afastado do que acolhido os sujeitos que chegam até ela.

Oliveira (2010) concorda com Street e argumenta que os PCN de língua portuguesa, por sua natureza oficial, apresentam caráter homogêneo, prescritivo e generalizante. Assim, o documento "constitui numa iniciativa de caráter amplo, nacional que visa oferecer princípios teóricos e diretrizes gerais para o ensino-aprendizagem de práticas letradas desejadas por determinados grupos que detêm o poder disciplinar" (p. 328).

Considerar o letramento como neutro, natural, singular, autônomo e visual é desconsiderar a complexibilidade e a diversidade da vida social engendrada pela linguagem utilizada nas mais diversas formas, nos mais variados tipos de interação social. A escola, ao considerar apenas o letramento autônomo e dominante, desconsidera essa diversidade e ignora que o que se escreve e “'o que' se lê e o 'como' se lê são fortemente determinados pelo 'lugar' de onde lemos” (OLIVEIRA, 2010, p. 330) e de onde escrevemos.

Em oposição a essa visão dominante de letramento, "com L maiúsculo e no singular" (STREET, 2014, p. 18), representante do que deve ser ensinado e seguido em muitas escolas, como uma violência simbólica (BOURDIEU, 2014), Street apresenta uma abordagem de letramento "como uma prática ideológica, envolvida em relações de poder e incrustada em significados e práticas culturais específicos” (2014, p. 13), considerando as práticas de letramento no plural.

Para tal, ele defende que é preciso ampliar a própria consideração sobre letramento e focalizar a multiplicidade das práticas letradas e o caráter social da leitura e da escrita, considerando que, além dos significados culturais, tais práticas são imbuídas de ideologias e de relações de poder, sendo "enganoso pensar em uma coisa única e compacta chamada letramento" (STREET; BAGNO, 2006, p. 466). Essa abordagem, fundamentada nos Novos Estudos sobre o Letramento, doravante NLS, requer a assunção de múltiplos letramentos "que variam de acordo com o tempo e o espaço, mas também contestados nas relações de poder" (STREET, 2014, p. 3).

Assim, o modelo ideológico de letramento legitima a multiplicidade de letramentos e seus usos como práticas sociais relacionadas a contextos culturais específicos permeados 
de relações de poder e ideologia. Os NLS $^{1}$ compreendem que o letramento varia nas diversas culturas, tal como os seus efeitos. Seus estudos buscam retratar as formas pelas quais as pessoas se relacionam e utilizam-se da leitura e da escrita nos mais diferentes contextos e condições.

Embora há tempo se reconheça, no campo da Linguística, a diversidade e heterogeneidade da língua, bem como seus usos e funções, e o "padrão" seja tomado como apenas mais uma variedade - sendo admitida hoje a perspectiva de normas cultas, no plural (FARACO, 2008) - a predileção pelo modelo autônomo e dominante de letramento ainda impera na sociedade e evidencia que

se trata de poder e de luta pela dominação, mais do que de um processo natural da emergência do 'melhor' como padrão. Eu gostaria de sugerir que adotássemos, de igual modo, a noção de letramento dominante a fim de salientar a extensão com que o letramento que é tratado como o padrão é apenas uma variedade entre muitas e que a questão de como ele se tornou o padrão é igualmente uma questão de poder. Isso implica, portanto, que nos refiramos a variedades de letramento tal como nos acostumamos a falar de variedades de língua. De que modo o letramento dominante marginaliza outras variedades, afirma sua própria dominação e disfarça sua própria base de classe e de cultura são questões que raramente têm sido levantadas no campo do letramento (STREET; BAGNO, 2006, p. 472).

Para Possenti (1996), a língua não é um produto homogêneo e abstrato, ela está sempre em construção, por isso todas variam (não só o português) e a variedade linguística é o reflexo da variedade social. Esta variação pode ocorrer por fatores externos (geográficos, de classe, idade, sexo, etnia, profissão etc.) e internos (contexto fônico, sintático etc.), por isso escolher uma metodologia para o ensino de língua portuguesa que trabalhe com uma concepção única de língua é um erro.

Gnerre (1991) demonstra historicamente que a variedade padrão está associada ao uso da escrita em ambientes de poder e aos conteúdos referenciais que veicula, fatores que atribuem a essa variante legitimidade como a que representa a tradição cultural e a identidade nacional. Como essa variedade está relacionada ao Estado e ao poder, que deveriam ser neutros, há a visão oficial, propositalmente produzida, de que a variedade padrão também é neutra. Mas, além da discriminação pela falta de domínio da variedade padrão, há também a distinção pela forma como as pessoas utilizam a linguagem quando não se aproximam de produções linguísticas de prestígio. Logo, seu uso reflete o poder e a autoridade que seus falantes têm nas relações sociais e econômicas.

\footnotetext{
${ }^{1}$ Os Novos Estudos do Letramento, ou New Literacy Studies (NLS), é uma abordagem em que o letramento é tratado de forma mais ampla e supera as questões relacionadas à alfabetização enquanto processo de aquisição da escrita e também uma abordagem na qual a dicotomia entre oralidade e escrita é relativizada.
} 
Em uma perspectiva histórica, ainda de acordo com Gnerre (1991), há a associação de uma determinada variedade linguística e o poder da escrita como exigências políticas e culturais desde a Idade Média. Na expansão colonial, Espanha e Portugal usaram suas línguas à dominação e à imposição de suas culturas. Neste sentido, a gramática ${ }^{2}$ representaria a norma imposta sobre a diversidade, como forma de legitimação e manifestação de poder do Estado, representando a língua oficial e, por esse motivo, é ensinada em processo de continuidade e necessidade sem a reflexão da sua origem e o que realmente representa.

É preciso, dessa maneira, compreender a variedade e a complexibilidade dos letramentos, questionar a superioridade de uma visão dominante e compreender que assumir a perspectiva do letramento autônomo é também em si mesmo uma posição ideológica, já que a aquisição, os usos e os significados dos diferentes letramentos têm caráter ideológico e implicam/engendram relações de poder.

Street (2014) adverte que esses modelos podem determinar recursos, currículos, influenciar propostas pedagógicas e estabelecer parâmetros para definir quem é e quem não é alfabetizado/letrado, portanto, "modelos poderosos pelas conseqüências que acarretam" (STREET, 2014, p. 37). É necessário, de acordo com Kleiman (2006), que a escola busque práticas pedagógicas sensíveis (ERICKSON, 1987) à cultura dos estudantes, de suas práticas sociais, para aproximar o aluno da escola, de forma que esta se torne significativa àquele.

Para Bakhtin (2003), a linguagem é social e em todos os diversos campos da atividade humana são produzidos tipos de enunciados relativamente estáveis denominados gêneros do discurso. Esses enunciados refletem as condições e as especificidades de um dado campo de comunicação e são constituídos indissociavelmente pelo conteúdo temático, estilo e estrutura composicional. Portanto, nas relações sociais, pelas necessidades de interação, os gêneros se configuram para atender as exigências dessas dadas situaç̧ões.

Conceber a linguagem enquanto interação, numa concepção sócio-histórica, permeada por questões ideológicas, e defender uma perspectiva de letramento ideológico no campo escolar possibilitam um processo de ensino crítico, cultural e sensível, proporcionando práticas escolares mais próximas de uma ação ativa e autoral frente às questões e às condições hegemônicas, reprodutoras da estrutura de poder.

\footnotetext{
${ }^{2}$ Segundo Antunes (2007), o termo gramática pode ter várias acepções, diferentemente de uma generalidade que a toma como única. A autora apresenta cinco definições de gramática que coexistem e que devem ser conhecidas pelo professor de língua materna, uma vez que a concepção adotada traz implicações ao processo de ensino. No contexto desse trabalho, entende-se que, ao usar o termo gramática, Gnerre (1991) refere-se a um conjunto de normas que regulam o uso da norma culta (Antunes, 2007). Essa concepção está associada a uma particularização da gramática porque representa apenas uma variação da língua tomada como de prestígio. Nessa abordagem, há o conceito de certo e de errado como formas de regular o que deve ou não deve ser dito e, subjacente a essa perspectiva, há questões históricas, socioeconômicas e ideológicas.
} 


\section{A Legislação Educacional Brasileira e o Letramento}

Com o uso do termo letramento nos documentos educacionais vigentes, como os Parâmetros Curriculares Nacionais (BRASIL, 1998) e as Diretrizes Curriculares da Educação Básica: Língua Portuguesa - DCE (PARANÁ, 2008), houve a difusão e a assimilação desse termo no discurso pedagógico. Entretanto, a mobilização desse conceito e sua aplicabilidade nas práticas pedagógicas parecem ainda muito distantes de seu real sentido. Compreender tal concepção e as implicações que decorrem da assunção da perspectiva do letramento nas atividades escolares, principalmente naquelas voltadas ao ensino-aprendizagem de língua materna, é uma necessidade para a busca de uma educação voltada às demandas da sociedade contemporânea e de seus sujeitos.

Muitas vezes, o professor de língua portuguesa fica muito preso a nomenclatura e regras gramaticais. Para Antunes (2007), a língua, além de um meio de comunicação, é um exercício de constituição da espécie humana; envolve cultura, sociedade, identidade, ideologias e não deve, portanto, ser simplificada durante o processo de ensino, pois tem mais a ver com sentido do que com exatidão. Para a autora, a língua também não é somente gramática, não basta somente estudar nomenclatura, pois o discurso não se constitui de regras gramaticais e, sim, de conteúdo, organização de ideias e coerência. Assim, torna-se necessário inspirar outro tratamento escolar para os fatos gramaticais, perceber que há mais elementos do que, simplesmente erros e acertos de gramática e de sua terminologia na língua.

Tal concepção sobre língua passou a nortear a elaboração de documentos oficiais de ensino, como os PCN (BRASIL, 1998) e as DCE (PARANÁ, 2008), os quais têm por finalidade subsidiar e orientar as discussões curriculares e, como um dos principais aspectos dessa orientação, considerar as práticas sociais e as demandas dos estudantes como pontos a serem observados na elaboração das ações pedagógicas.

O texto de apresentação dos Parâmetros Curriculares Nacionais do Ensino Fundamental - Língua Portuguesa (BRASIL, 1998) destaca essa nova realidade e adverte que, com a crescente exigência do uso da escrita e da leitura nas sociedades modernas e com o recebimento de um número cada vez maior e heterogêneo de alunos na escola pública, métodos e conteúdos tradicionais tornaram-se anacrônicos para conciliar e atender tais demandas. Segundo os PCN (p. 21), "Ser um usuário competente da escrita é, cada vez mais, condição para a efetiva participação social".

Diferentemente do caráter orientador dos PCN, que têm como objetivo serem referência às discussões curriculares, bem como contribuírem para a elaboração e ressignificação de propostas didáticas, as Diretrizes Curriculares Nacionais para a Educação Básica - DCN (BRASIL, 2013), instituídas em 2013 e pautadas na Lei de Diretrizes e Bases da Educação - LDB (BRASIL, 1996), são normas obrigatórias do planejamento escolar, da elaboração do currículo, e que garantem o conteúdo mínimo a ser ensinado. Essas diretrizes deliberam que a Educação Básica 
é direito universal e alicerce indispensável para a capacidade de exercer em plenitude o direito à cidadania. É o tempo, o espaço, e o contexto em que o sujeito aprende a constituir e reconstituir a sua identidade, em meio a transformações corporais, afetivo-emocionais, socioemocionais, cognitivas e socioculturais, respeitando e valorizando as diferenças. Liberdade e pluralidade tornam-se, portanto, exigências do projeto educacional (BRASIL, 2013, p. 17).

Mediante tal desafio, o ensino de língua portuguesa deve proporcionar aos alunos o desenvolvimento e a ampliação do domínio da linguagem, principalmente no tocante à leitura e à escrita, fundamentais no contexto atual para o exercício da cidadania.

Os PCN, dentro do tópico "Organizações Didáticas Especiais”, trazem como orientação ao professor o trabalho com projetos. Na mesma direção do que se preconiza nos projetos de letramento, o documento mencionado diz que a característica precípua de um projeto é que seu objetivo seja compartilhado por todos os integrantes e expresso em um produto final, “em função do qual todos trabalham e que terá, necessariamente, destinação, divulgação e circulação social internamente na escola ou fora dela” (BRASIL, 1998, p. 87).

O documento ainda ressalta que o trabalho com projetos favorece a flexibilização do tempo das atividades escolares para o alcance do objetivo proposto e que eles podem permitir ao aluno participar do planejamento das atividades, assim como contribuem para que o aluno tenha compromisso com seu processo de aprendizagem, tornando-se sujeito ativo e engajado nas tarefas. Os PCN também destacam que os projetos "oferecerem condições reais para a escuta, leitura e produção de textos orais e escritos” (BRASIL, 1998, p. 87), de forma que o trabalho com a língua passa a ser contextualizado, atribuindo sentido às atividades escolares, pois

- criam a necessidade de ler e analisar grande variedade de textos e suportes do tipo que se vai produzir: como se organizam, que características possuem ou quais têm mais qualidade. Trata-se de uma atividade de reflexão sobre aspectos próprios do gênero que será produzido e de suas relações com o suporte; [...]

- colocam de maneira mais acentuada a necessidade de refacção e de cuidado com o trabalho, pois, quando há leitores de fato para a escrita dos alunos, a legibilidade passa a ser objetivo deles também, e não só do professor [...] (BRASIL, 1998, p. 87-88).

Conforme Hernández (1998), os projetos de trabalho permitem à escola aproximarse da identidade dos alunos e favorecem a construção da subjetividade; revisar a organização do currículo por disciplinas e a maneira de situá-lo no tempo e no espaço escolar; levar em conta as transformações sociais e as produções de informação. Os projetos de trabalho supõem um enfoque de ensino que trata de ressituar a concepção e as práticas escolares para dar resposta às mudanças sociais. Eles são um meio pelo qual se pode repensar e refazer a escola, tentando reorganizar a gestão do espaço, do tempo, da relação entre docentes e alunos para redefinir o discurso sobre o saber escolar, considerando o atual contexto. 
Aliás, para o educador, são as diferenças do contexto que distinguem práticas e formulações dos atuais projetos dos que já foram propostos em outras épocas.

\section{O Jornal Escolar em Construção}

Freinet (1974), considerado o precursor do trabalho com o jornal escolar, acredita que é imprescindível partir das experiências e interesses dos alunos, bem como considerar a realidade social e cultural dos estudantes para o desenvolvimento de atividades de escrita. Para o autor, essa forma de trabalho propicia a elaboração de textos autênticos, em que os alunos realmente tornam-se autores de suas produções: "Um jornal escolar não está, não pode estar, não deve estar ao serviço de uma pedagogia escolástica que lhe diminuiria o alcance. Deve estar, sim, à medida de uma educação que, pela vida, prepara para a vida" (p. 78).

Ao discutir sobre as vantagens pedagógicas do uso do jornal escolar método Freinet, o autor volta-se a mais uma importante questão: a criança ter um correspondente real no momento da escrita. A não artificialidade das produções torna a criança motivada para escrever porque ela sabe que seu texto não será apenas corrigido, mas lido, ultrapassando os muros da escola e a função meramente escolar, como se defende nos projetos de letramento. Nesse aspecto, Freinet (1974, p. 86) ainda destaca que a escola, dessa maneira, adquire "um sentido, um objetivo e um significado".

Tendo como base as orientações de Freinet e a necessidade de utilização das questões dos alunos e da comunidade escolar para o desenvolvimento dos conteúdos curriculares, principalmente da língua materna, decidimos também elaborar um jornal escolar com a turma como projeto de letramento.

A implementação do projeto do jornal escolar estava prevista como uma atividade do terceiro bimestre do ano letivo de 2017 da turma participante. Como o livro didático do $9^{\circ}$ ano adotado na escola traz inúmeros gêneros da esfera jornalística, esses foram reorganizados de forma que tais conteúdos concentraram-se nesse período. Para essa organização, considerou-se a necessidade do trabalho com os conteúdos previstos para essa série, assim como a criação de condições mais favoráveis para a utilização do livro didático. Nesse contexto, esse material passou a ser de apoio ao trabalho do professor para um fim maior do que a mera resolução dos exercícios ou o término de unidades previstas.

Para iniciar as atividades e desenvolver um trabalho assertivo, aplicamos na turma uma pesquisa sobre práticas de letramento dos alunos em relação à leitura de jornal e às fontes de informação. Tal questionário foi formado com 20 perguntas de múltipla escolha e abertas e teve como objetivo entender de que maneira os alunos buscavam informações e quais as formas de mídias eram mais utilizadas por eles. Além disso, analisar a frequência da utilização desses meios de comunicação e a percepção de confiabilidade pelos alunos das notícias divulgadas por essas mídias. Por fim, verificar se os alunos conseguiam estabelecer alguma relação entre os conteúdos estudados na disciplina de língua portuguesa, mais especificamente sobre os gêneros discursivos da esfera da imprensa muito recorrentes nos 
materiais didáticos do ensino fundamental, com as demandas sociais de leitura e escrita, devido ao objetivo do projeto de letramento de desenvolver o jornal escolar do colégio.

Depois de compreendermos um pouco a relação dos estudantes com a mídia, o trabalho desenvolveu-se no sentido de instrumentalizar os alunos em relação ao jornal e suas características. Com exemplares de jornais locais, estaduais e de circulação nacional, conseguidos como doação, os alunos buscaram as regularidades de um jornal e iniciaram as discussões sobre extensão, diagramação, linha editorial e outros temas voltados à elaboração do jornal da escola. Houve também momentos para o cotejamento de matérias jornalísticas, bem como a análise de manchetes e imagens utilizadas na primeira página, para que se pudesse discutir o conceito de linha editorial.

As atividades com textos autênticos deixaram o trabalho mais real e próximo das práticas sociais. Embora o livro didático da turma de aplicação do projeto seja composto por vários gêneros da esfera jornalística, como notícia, reportagem, artigo de opinião etc., o deslocamento do texto de seu contexto de produção e circulação torna o processo de aprendizagem mais artificial. No livro didático também não é possível compreender o que é um jornal e, sim, apenas parte dele.

Assim, já no início do projeto, a leitura e a escrita perpassavam as atividades na sala de aula e eram fundantes para o desenvolvimento do projeto: ler, observar, analisar, cotejar, anotar, sintetizar as características do jornal para a construção de um modelo.

Outra questão abordada nesse momento foi a de qual linha e função o jornal produzido pelos alunos teria dentro do contexto escolar. Assim, junto à turma, houve a reflexão e a conclusão de que o jornal serviria para trazer informações relevantes sobre a escola e a comunidade escolar, ajudando na divulgação de projetos, atividades e ações que acontecem nesse espaço, bem como uma possibilidade de dar voz aos estudantes em relação a determinados assuntos que têm implicações diretas na vida escolar, como o uso do uniforme, a prática de bullying na escola, assuntos de matérias publicadas posteriormente no jornal.

Os alunos, ainda nessa fase, assistiram ao documentário O Mercado de Notícias ${ }^{3}$ de Jorge Furtado, para compreenderem como o mercado e o capital estão relacionados à produção e veiculação de matérias, assim como debaterem o papel da imprensa, hoje, na sociedade e na formação da opinião pública.

Para o desenvolvimento dessa atividade, houve a leitura de uma notícia mencionada no vídeo, para que os alunos entendessem as críticas colocadas à falta de veracidade no que é, muitas vezes, produzido pela mídia.

\footnotetext{
${ }^{3} \mathrm{O}$ referido documentário encontra-se disponível em <http://www.omercadodenoticias.com.br/>. O site também apresenta informações de como a obra foi produzida, bem como depoimentos de jornalistas, curiosidades, premiações do documentário e outras informações que podem ajudar o professor na hora de elaborar sua aula.
} 
Além dessa preparação para o filme, os alunos leram resenhas para entenderem a organização do documentário, já que é um gênero com o qual eles têm pouco contato. Também houve a parceria com o professor de geografia da turma para que ele contribuísse com as discussões abordadas no vídeo, como a função e o funcionamento do jornalismo, a manipulação dos fatos etc.

Depois de feitas as discussões sobre a produção de Jorge Furtado, os alunos escreveram um pequeno comentário sobre a obra. A atividade com o documentário possibilitou aos alunos o contato com vários gêneros: notícia, resenha, debate, o próprio documentário. Todos esses serviram como apoio para o primeiro texto produzido para o jornal: um comentário sobre o filme. Dentre esses textos, um foi selecionado para ser publicado no jornal, uma vez que o referido documentário é pouco difundido nas escolas e poderia ser trabalhado em outros momentos por outras disciplinas. Além disso, ele atende ao objetivo de formar leitores e telespectadores críticos.

À medida que o projeto avançava, foi preciso também aproximar os alunos de um contexto de produção real de um jornal. Para isso, um jornalista foi convidado para falar sobre a profissão e ajudar no entendimento de questões pertinentes ao jornalismo, além de oportunizar ao aluno a possibilidade de conhecer uma profissão com a qual ele tinha pouco contato.

Para tornar a atividade mais dinâmica e para que os alunos participassem ativamente, houve a decisão de transformar a visita do jornalista em uma entrevista que seria realizada e organizada pelos próprios alunos. Assim, os alunos pesquisaram, leram, assistiram entrevistas e, em equipes, elaboraram, escreveram e "praticaram" a oralidade para o momento da conversa.

Para Marcuschi (2007), não se deve tratar as relações entre oralidade e letramento de maneira estanque e dicotômica; o autor propõe que essas relações sejam vistas dentro de um quadro mais amplo dentro do contexto das práticas comunicativas e dos gêneros textuais. Ele parte do princípio que são os usos que fundamentam a língua, e não o contrário; por isso não faz sentido falar da língua fora do seu contexto. Para ele, saber usar a língua adequadamente não é decorar uma série de regras gramaticais e, sim, conseguir adequar a língua para produzir um efeito de sentido pretendido numa determinada circunstância. A situação criada (entrevista) permitiu que a oralidade fosse integrada ao projeto de letramento.

Para Bakhtin (2003), aprender a falar é aprender a estruturar enunciados, pois falamos por enunciados e não por orações ou palavras isoladas. Os gêneros do discurso organizam a nossa fala da mesma maneira que a organizam as formas gramaticais, aprendemos a moldar a nossa fala às formas do gênero que iremos usar. É preciso saber selecionar o gênero para organizar um discurso, o que implica conhecer suas características, avaliar sua adequação aos objetivos e o contexto no qual irá circular, por isso a entrevista foi planejada previamente. 

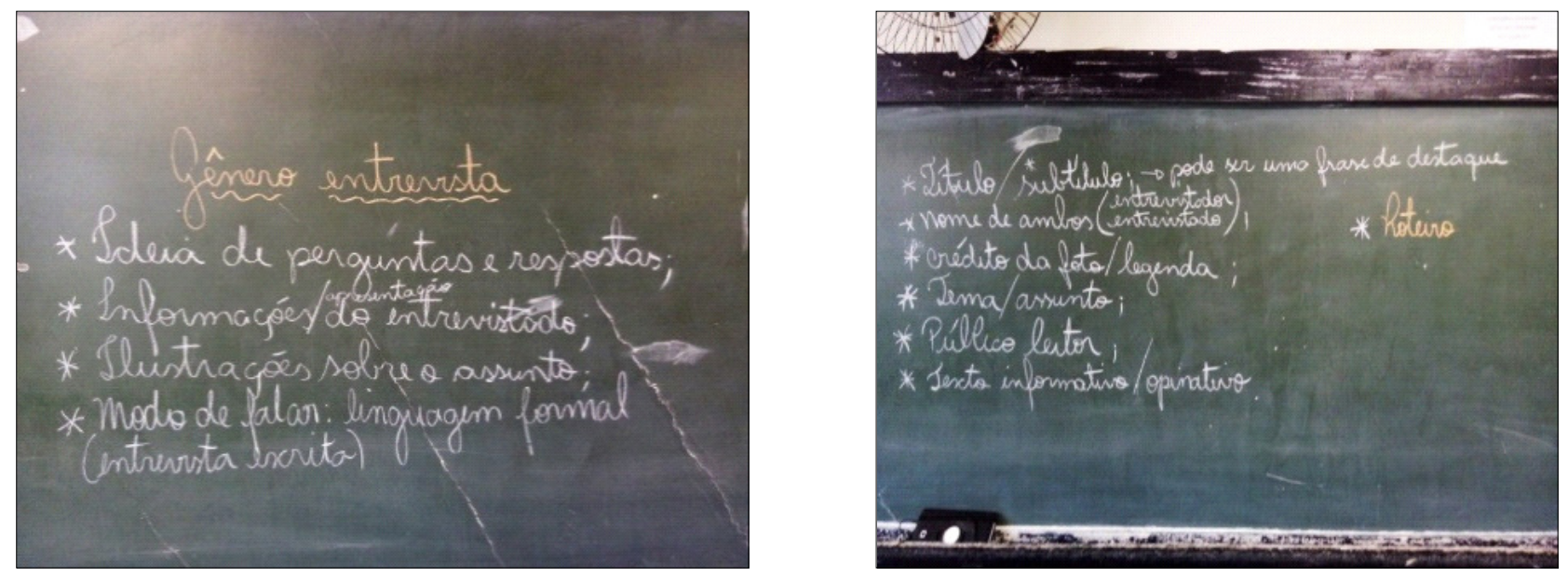

Fonte: Geração de Dados - Professora/Pesquisadora, 2017.

Figura 1 - Anotações no quadro sobre as regularidades do gênero entrevista

A entrevista foi gravada e cada equipe, como tarefa, ficou responsável por fazer a transcrição de uma parte. Essas informações, além de ajudarem os alunos a entenderem melhor o jornalismo em si, também seriam utilizadas para que outra matéria do jornal fosse produzida.

\section{"6 A função do bom jornalismo hoje é efetivamente investigar e informar 9}

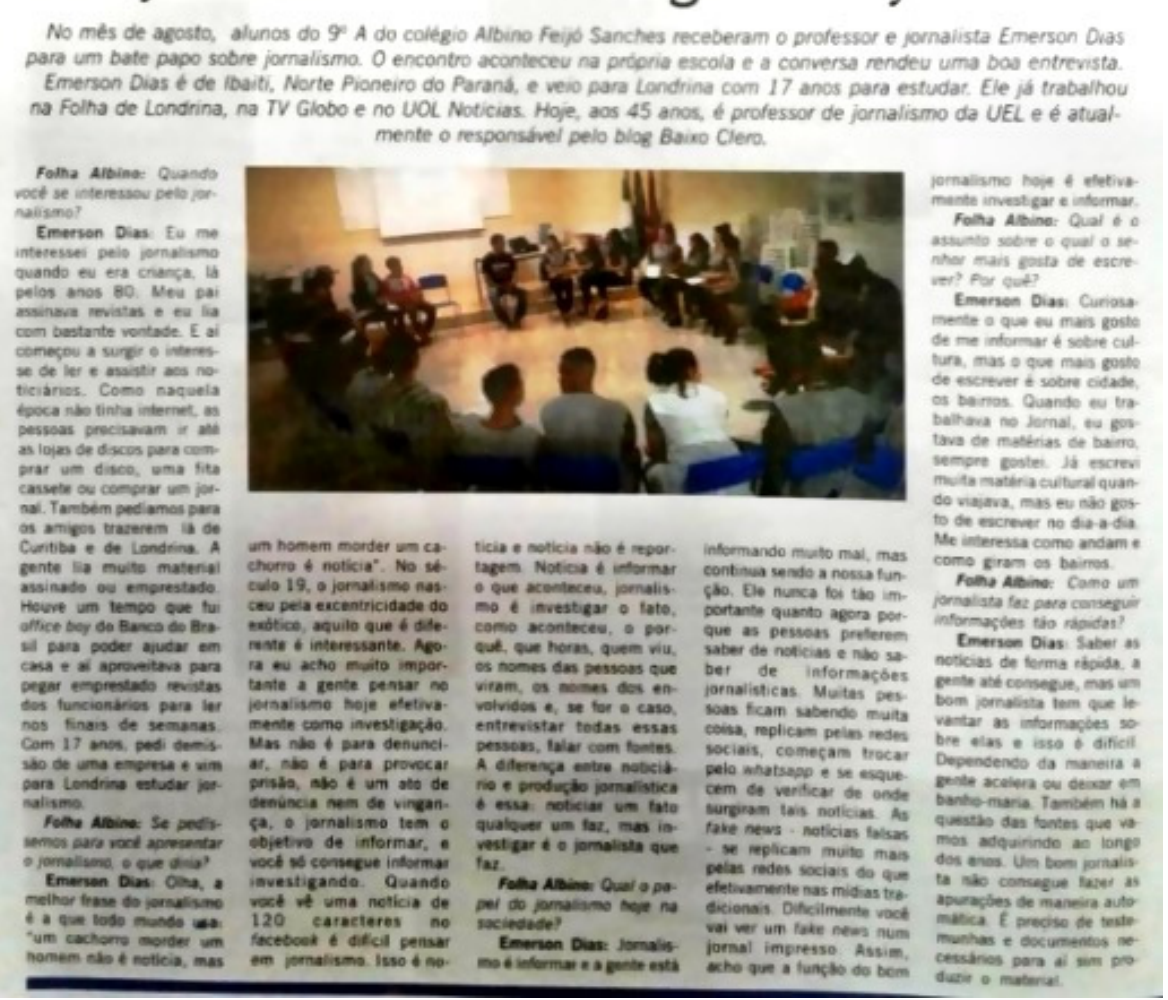

Fonte: Folha Albino, Londrina-PR, ago. set. 2017.

Figura 2 - Entrevista como parte integrante do jornal 
Como os alunos enviaram as transcrições por e-mail, foi possível projetar alguns excertos no datashow e reescrevê-los coletivamente. Esse processo de retextualização serviu para mostrar aos alunos como eles fariam; também ajudou na identificação de algumas características da modalidade oral da língua e no trabalho com questões referentes à pontuação, por exemplo.

O trabalho com o gênero associa a produção de texto a sua função social, neste projeto de letramento a escrita tornou-se uma prática social; por isso o destinatário, os meios de circulação dos textos e o porquê estão sendo escritos foram aspectos importantes. É preciso criar no aluno o hábito de planejar, escrever, revisar e reescrever seus textos, o aluno perceberá que a reformulação da escrita não é motivo para constrangimento (MARCUSCHI, 2007).

Iniciou-se, nesse momento, o trabalho com as pautas que, na linguagem jornalística, dizem respeito aos assuntos que orientam a elaboração de uma matéria abordada na edição de um jornal. O objeto do trabalho com a elaboração de pautas é possibilitar ao aluno um olhar mais crítico sobre a própria escola e seu entorno, assim como desenvolver nos estudantes a percepção de questões pontuais e de relevância para a comunidade escolar.

Para a produção das pautas, os alunos também assistiram a vídeos de circulação na internet sobre a definição de jornalismo e elaboração de pautas, produzidos por uma agênciaescola de jornalismo. Além disso, pesquisaram sua definição, como tarefa, e trouxeram para a aula exemplos de pautas jornalísticas.

Além das questões referentes ao domínio do conceito de pauta e de sua identificação enquanto gênero, os alunos participaram de uma atividade extraclasse interdisciplinar. Com um mapa do bairro desenvolvido pelo professor de geografia, os alunos, com cadernos e celulares, caminharam pelo entorno da escola para identificarem questões possíveis ao desenvolvimento de matérias para o jornal.

O mapa ajudava na localização e os alunos iam marcando nele pontos que estavam relacionados ao medo ou à sensação de bem-estar. Durante a atividade, também já foi possível conversar sobre o porquê de tais sentimentos, observando os elementos que compunham o espaço analisado. Dois conceitos foram trabalhados antes e durante essa atividade: topofobia e topofilia.

Depois da caminhada pelo bairro da escola, os alunos começaram a selecionar pautas para o desenvolvimento das notícias. Primeiro, de forma individual, cada aluno pensou em questões possíveis para a elaboração das matérias referentes à escola e à comunidade. Depois, houve a compilação nas equipes.

No momento seguinte, a professora organizou junto aos alunos as questões que serviriam de pautas ao jornal. Como a produção das matérias aconteceria nas semanas seguintes, houve uma tendência das pautas não tratarem apenas de fatos pontuais, mas sim de fenômenos observáveis na escola e na comunidade.

Para o fechamento das pautas, houve também a discussão se alguns temas seriam ou não pertinentes, nesse momento, para serem tratados no jornal. 
Outra questão também importante para ser levantada em relação à construção das pautas refere-se à necessidade dos alunos de pesquisarem e entenderem melhor a própria organização e desenvolvimento da escola e do entorno escolar. A consciência desse funcionamento os torna sujeitos mais críticos e mais propícios à ação cidadã.

O gênero notícia pode ser considerado o principal gênero trabalhado para a elaboração desse jornal escolar. Entretanto, a definição por esse gênero não estava relacionada a uma ideia curricular ou porque tal gênero faz parte dos conteúdos selecionados para serem desenvolvidos no último ano do ensino fundamental. A escolha pela notícia estava atrelada à função que o jornal ocuparia dentro do espaço escolar. Já que a linha editorial definida junto aos alunos relacionava-se à ideia de divulgar e informar à comunidade escolar as ações que acontecem no colégio, o gênero notícia é o que mais atendia a esse objetivo, além, é claro, de ser um dos gêneros centrais de um jornal.

Para o desenvolvimento do trabalho e a sequência de ensino do gênero notícia, foram selecionadas notícias veiculadas na mídia sobre a própria escola e sobre os alunos. $\mathrm{O}$ objetivo dessa atividade era o de buscar temas que estivessem relacionados ao universo dos estudantes e que também se configurassem como textos autênticos, para que a atividade se aproximasse o máximo possível das reais práticas do uso da escrita e da leitura. Ao invés de buscar qualquer tipo de notícia, sobre qualquer assunto, de forma artificial e desvinculada da realidade da comunidade escolar, selecionaram-se, em algumas atividades com o gênero, notícias locais.

Nas notícias selecionadas para sala de aula e com jornais diversos, houve o trabalho de localização do que, na linguagem jornalística, chama-se pirâmide invertida. Com um quadro dessa pirâmide - estrutura do gênero notícia - os alunos localizaram e compreenderam tal estrutura, formada, geralmente, por: título, subtítulo e intertítulo, se houver; pirâmide invertida (lide: O quê? Quem? Onde? Quando?) e o corpo ou desenvolvimento (Como? Por quê?).

Depois de trabalhadas algumas questões sobre o referido gênero, como estrutura e organização, inclusive com atividades disponíveis no próprio livro didático da turma e atividades de interpretação de notícias para distinção de fato e versão, cotejamento entre notícias, cada equipe selecionou da tabela de pautas elaborada um assunto para ser desenvolvido como matéria jornalística.

Para facilitar o processo de produção da notícia, cada equipe também produziu uma pauta jornalística referente à questão selecionada. A produção dessa pauta, além de oportunizar ao aluno uma experiência mais real da profissão e um momento de produção textual outro, que ultrapassa a ideia de apenas correção do professor, possibilitou a escrita da notícia de forma organizada e pensada. Com a noção dos elementos que precisam buscar e pesquisar, com o conhecimento da estrutura desse gênero e com um motivo real para a sua produção, houve pouca dificuldade na hora de produzir as matérias. 


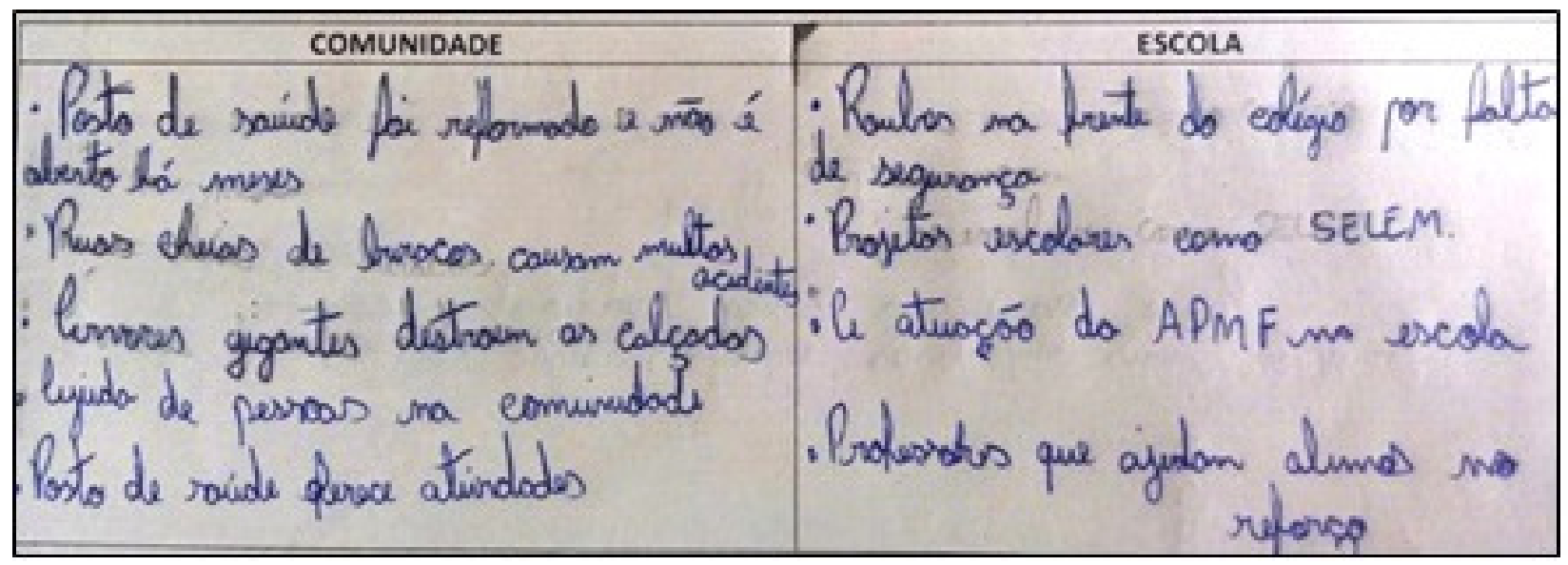

Fonte: Geração de Dados - Professora/Pesquisadora, 2017.

Figura 3 - Exemplo de levantamento de pautas pelos alunos

As matérias estavam sendo produzidas no computador, em duplas ou trios; nesta troca, muitos problemas referentes ao uso das regras da norma culta eram percebidos e corrigidos pela própria equipe. Para Antunes (2007), é preciso se fixar no uso da língua e nos efeitos obtidos a partir da utilização de determinado recurso. O trabalho de reflexão linguística a ser realizado com esses alunos deve voltar-se para a observação e análise da língua em uso, o que inclui morfologia, sintaxe, semântica e estilística; variedades linguísticas; as relações e diferenças entre língua oral e língua escrita, visando à construção de conhecimentos sobre o sistema linguístico. Partindo do pressuposto que o texto é a única forma de se usar a língua, "A gramática é constitutiva do texto, e o texto é constitutivo da atividade da linguagem. [...] Tudo o que nos deve interessar no estudo da língua culmina com a exploração das atividades textuais e discursivas" (ANTUNES, 2007, p. 130).

Sem deixar de trabalharmos a norma culta, foi ressaltado que o fato de que ela ser a norma prestigiada não significa que seja a única que merece ser validada como legítima representante da língua. Todas as variações linguísticas são legítimas, é necessário adequar os usos às condições da situação. Assim, o trabalho da professora foi de estimular a reflexão sobre o uso da variante linguística adequada para aquele gênero e na ampliação da matéria, com sugestões sobre o desenvolvimento da argumentação e a progressão do texto.

O resultado final foi bastante satisfatório: 


\section{Posto na Zona Sul demora para ser reinaugurado}

O secretário municipal de Obras e Pavimentaçăo, Walmir Matos assinou em 07 de novembro de 2016 uma ordem de serviço para a reforma da Unidade Básica de Saúde PIND. A obra teve inicio 5 dias úteis após a assinatura do documento, em 15 de novembro de 2016 e o fim da reforma foi estimado para 180 dias (06 meses). Porém, a obra só foi concluida 4 meses após a data prometida, em setembro de 2017

O prédio da UBS apresentava muitos problemas na estrutura e precisava de uma reforma. "Para surpresa de todos, numa vista geral. vi que está muito bonito. Foi tudo reformado, nova pintura, troca da parte hidráulica dos banheiros, o consultório médico, portas novas etc. De um modo geral o posto de saúde da unidade básica do Parque das

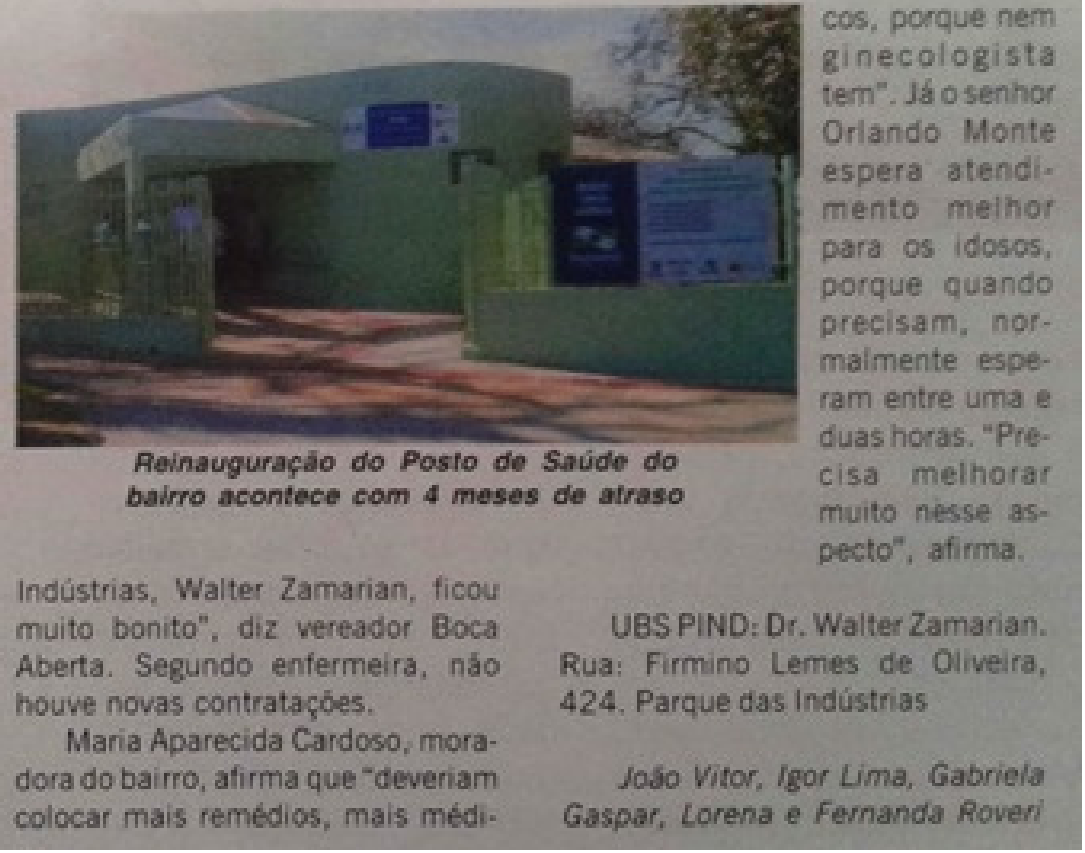

Fonte: Folha Albino, Londrina-PR, ago. set. 2017

Figura 4 - Uma das notícias produzidas para o jornal escolar

Nesse momento de elaboração do jornal, as atividades eram muito diversificadas e os alunos tinham contato com muitos textos para a produção: reconhecimento e leitura de diversos gêneros, busca de suas regularidades, seleção do gênero que melhor se aplicava aos objetivos do jornal e de sua linha editorial. Também o trabalho com a oralidade era frequente e constante, não só porque os alunos efetivamente realizaram entrevistas, mas também porque produzir em equipe requer negociação, posicionamento e argumentação para que uma decisão seja tomada, tanto no que se refere à escrita, como também no momento de definir qual pauta selecionar, qual imagem, quem entrevistar, que informações incluir e quais descartar.

Para a elaboração do editorial do jornal, por exemplo, uma equipe foi selecionada para ser a voz da turma e representar a posição dos alunos. Depois da pesquisa sobre o gênero editorial e da leitura de alguns exemplos nos jornais levados à sala de aula, inclusive de jornais locais, porque são menores e poderiam dar uma ideia mais próxima do que os alunos precisavam, a equipe decidiu fazer o editorial sobre o processo de elaboração do jornal e do objetivo desse veículo no âmbito escolar. 


\section{EDITORIAL}

Nos dois últimos meses, a professora Ana Paula da Silva, da materia de Lingua Portuguesa, nos propós a criagáo de um jornal escolar que abordasse diversos assuntos do próprio colégio e da comunidade. A turma gostou e apoiou a ideia, prontificando-se a criar o jornal.

Isso nos ajudou a olhar com outros olhos para certas situaçces que ocorrem em nossos bairros e escola, criticando e refletindo sobre certos assuntos como, por exemplo, uma simples sujeira nas calçadas. isso nos fez pensar em como as pessoas nalo cuidam do que é delas mesmas, algo que náo pensávamos antes dessa experiência.

O objetivo do jornal, alem de interagir com os leitores, informar. aconselhar, influenciar a leitura, tem também o objetivo de levar conhecimento para pessoas sobre o que acontece em volta de suas casas e o que acontece dentro da nossa escola.

Fonte: Folha Albino, Londrina-PR, ago. set. 2017.

Figura 5 - Editorial produzido para o jornal escolar

No processo de elaboração das matérias para o jornal, houve na turma de aplicação do projeto um caso de bullying. Tanto agressor quanto vítima eram alunos do $9^{\circ}$ ano. Para ajudar na solução desse problema, houve a sugestão por parte da professora de que os alunos escrevessem um artigo de opinião para ser publicado no jornal.

Esse gênero já havia sido trabalhado durante o ano letivo e também estava presente no livro didático, fazendo parte dos conteúdos dessa série. Para o desenvolvimento dessa atividade, trabalhou-se um texto informativo de uma revista de educação. Tal texto trazia informações importantes, como a definição do que é bullying, quem é o agressor, dos danos causados por essa ação etc.

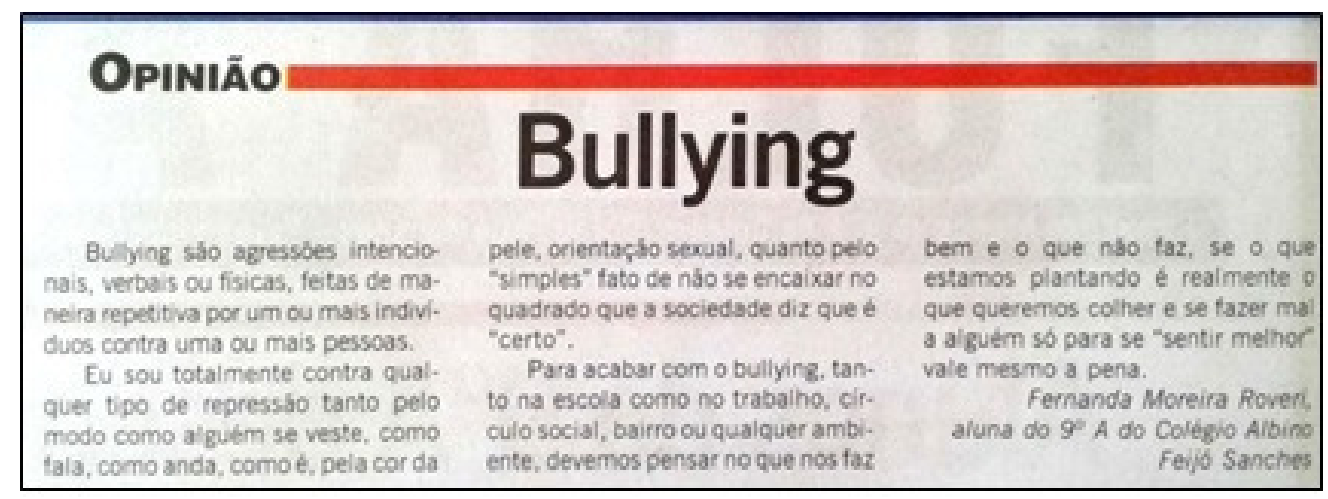

Fonte: Folha Albino, Londrina-PR, ago. set. 2017.

Figura 6 - Artigo de opinião produzido por um aluno para o jornal Folha Albino

Depois desse processo, cada aluno produziu seu próprio artigo para ser publicado no jornal, manifestando sua opinião sobre o tema abordado e o melhor texto foi selecionado para publicação. 
Também houve a produção de uma enquete. A produção da enquete foi sugestão de alguns alunos que gostariam de manifestar a opinião deles sobre assuntos relacionados à escola. Assim, os alunos decidiram que fariam a enquete sobre o uso obrigatório da calça preta como uniforme.

Sobre a enquete, duas alunas assumiram o trabalho de elaboração e aplicaram uma pergunta sobre o uso da calça preta para algumas turmas. Os alunos entrevistados precisariam responder se concordavam com a calça preta, se discordavam ou se não tinham opinião sobre o assunto.

É valido destacar que a ideia inicial para a produção da enquete estava voltada, por parte dos alunos, a uma crítica ao uso obrigatório da calça preta e do uniforme de forma geral. Para eles, havia uma postura autoritária e intolerante da escola, já que havia sanções para os alunos que descumprissem tal regra. Como a função do jornal deveria ser a de informar, buscando a imparcialidade, os alunos precisaram entrevistar a direção do colégio. $\mathrm{Na}$ entrevista, compreenderam que a escola organizou uma reunião no ínício do ano letivo e os participantes referendaram o uso da cor preta.

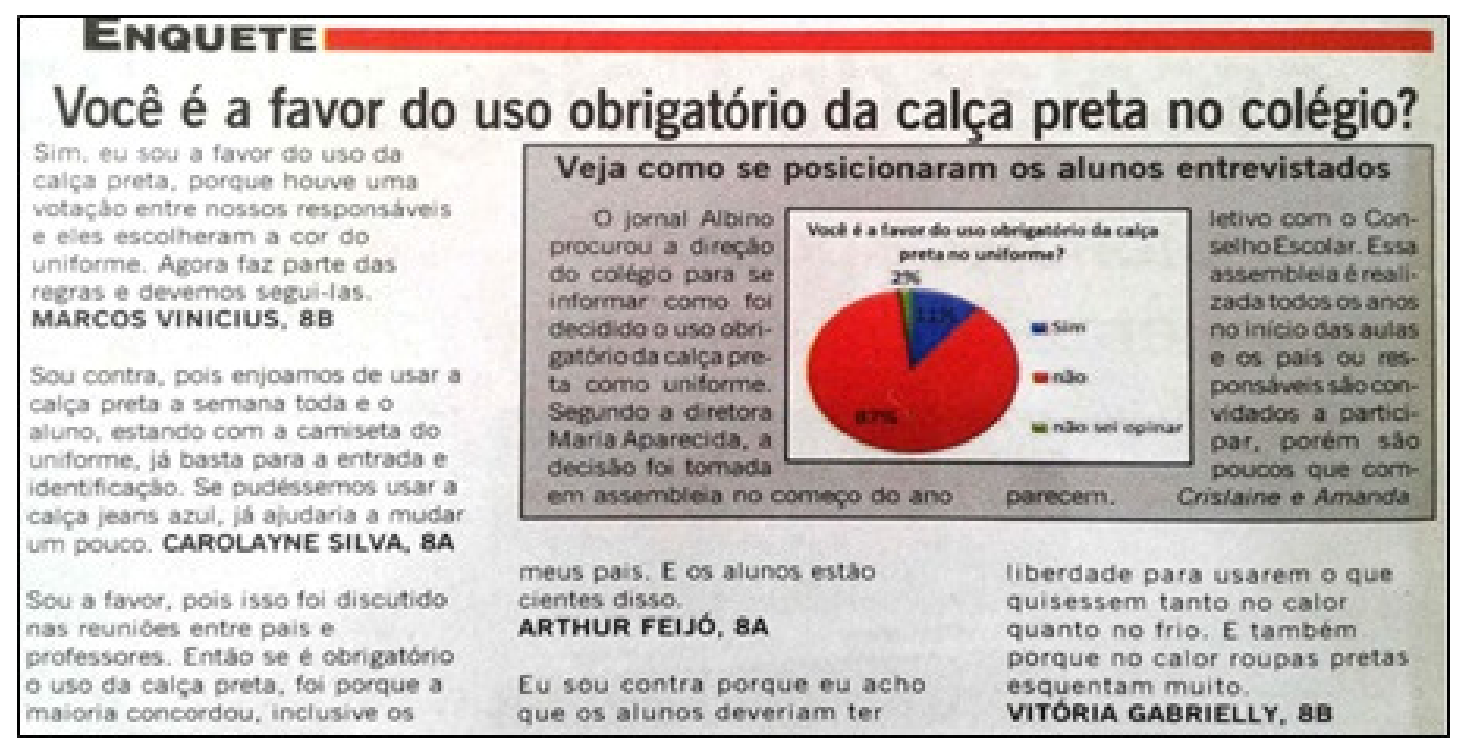

Fonte: Folha Albino, Londrina-PR, agosto e setembro de 2017.

Figura 7 - Enquete produzida para publicação no jornal da escola

Essa informação fez com que os alunos compreendessem a importância da participação dos responsáveis nas reuniões escolares, assim como serviu para informar aos demais leitores do jornal como fora realizada a definição do uniforme. 


\section{FOLHA ALBINO}

Jornal dos Alunos do 92 A do Colégio Albino Feij6 Sanches - Parque das Indústrias - Londrina - PR I Agosto/Setembro - 2017 - $1^{2}$ Ediçăo

Projeto de Jornalismo

\section{Alunos do $9^{\circ} \mathrm{A}$ desenvolvem jornal escolar do Colégio Albino Feijó Sanches}

\section{Biblioteca pouco frequentada na zona sul}

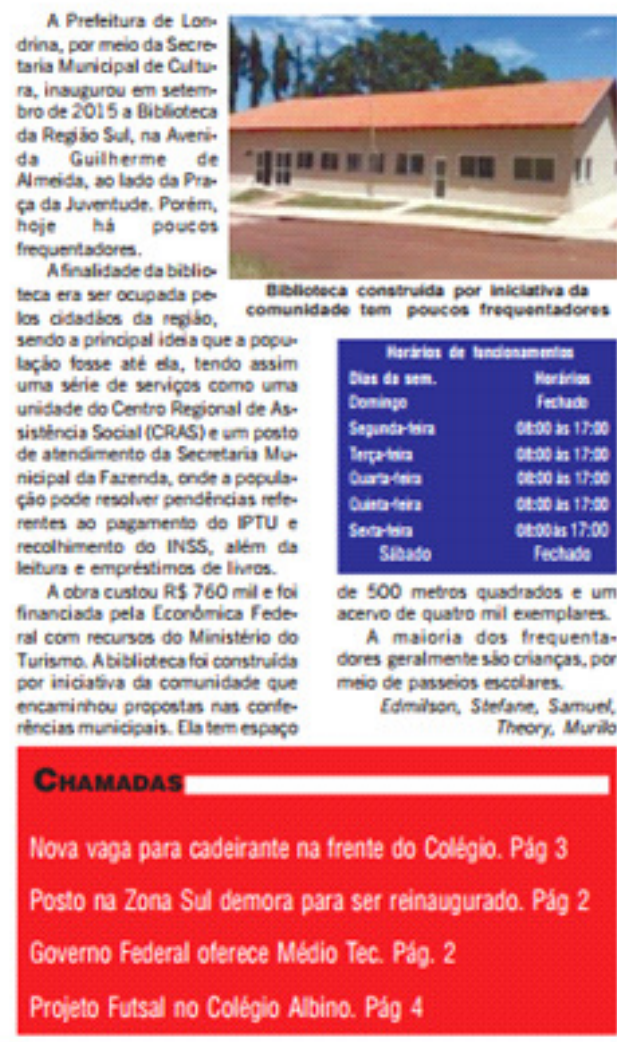

Os alunos do GrA do Colteglo Nubino Feijo Sanches e a peo fessora Ana Paula, de Lingua Portuzuesa, no mits de acosto setembro, desenvolveram um proieto para a elaboracío do jornal da escola. Um dos objetivos et criat um jomal que fale sobere os interesses da comunidade e do coltexio.

Os alunos foram divididos em equipe e cada uma floce respors thel por produair materi. as para o jomal, depois de alevmas aulas de preparacto, sobre como produzir generos jornalisticos.

Além do objetivo de tazer um jornal informathosobre a comunidade e ocoliegio, outro objetivo do projeto é fazer com que os alunos entendam melhor sobre a midia impressa edesconfiem mais das noticias, aprendendo

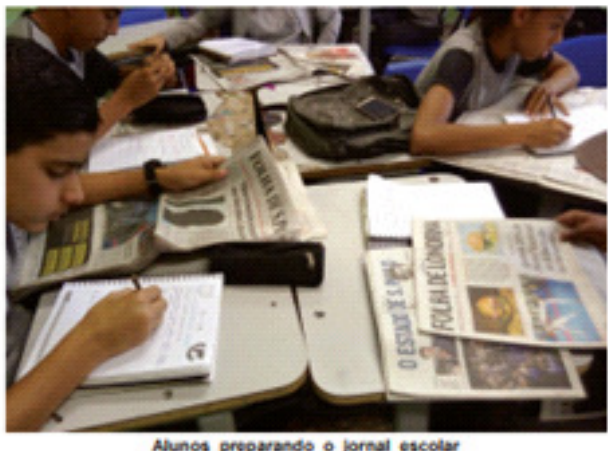
Alunos preparando o formal escolar analisa-las melhor, altem de for baliho dos jornalistas", atirmo mar a coinido cidada dos estu. a estudante e participante do dantes. Eu acho que o tato de projeto Thais Eloisa da Silva. azermos penalismo faz comque Gabriela.B, Melissa. criemos uma opinibo e tambem Samuet, Kavane, Gustavo

\section{Projeto futsal}

Projeto Futsal de base aberto à comunidade Iondrinense funciona no Colégio Albino Feijó

\section{0 projeto de futsal teve inioio} om $2014 \mathrm{com}$ a necessidade da busca pelo esporte, que sompre fol um ponts forte do coltegia. lriciov. secoma categoria sub 17 nos josen
ecelares e depois se ewendeescilares o depois se eilendey

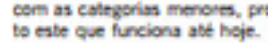

Todos es slunos partidipam de loges dos campeonstos aco finsis de semana. Pelo grande numero de alunios no projeto, e feito um reveramento dos alunos para que todos possam particioar dos cam. peonatos e des treinos.

Cada ensortinta contibui esm ma tau menasi de RS40,00par: ajudar na compra dos muterisis

Fonte: Jornal produzido pelos alunos do $9^{\circ}$ ano

Figura 8 - Imagem do jornal finalizado

A primeira edição do jornal foi publicada com: notícias, editorial, charge, enquete, entrevista, comentário de filme e de livro, artigo de opinião, manchete, propaganda, chamadas e expediente. No total, mil cópias foram impressas e o jornal foi distribuído aos alunos e à comunidade escolar. 


\section{ConClusão}

O trabalho com jornal, por sua natureza prática e com função social, revelou-se como um recurso pedagógico viável e privilegiado ao trabalho com a língua portuguesa, principalmente na modalidade escrita, e também como um recurso capaz de mobilizar uma série de questões relacionadas à vida dos alunos e de questões de suas comunidades, despertando o interesse desses jovens pela escrita enquanto forma de participação social e autoria. A experiência de desenvolver um jornal, que teve como objetivo informar aos leitores assuntos do colégio e da comunidade escolar, contribuiu para a formação crítica e cidadã desses jovens, uma vez que puderam experienciar o uso da escrita com função social, legitimada pela mídia impressa, tornando-se protagonistas do processo ensino-aprendizagem, já que a escrita desenvolvida por eles teve utilização real no espaço escolar.

Nesse aspecto, é importante destacar também que a experiência com o trabalho do jornal enquanto projeto de letramento ampliou nos alunos e na professora a noção do processo de ensino-aprendizagem. Ao considerar a promoção da função social da escrita articulada com o desenvolvimento de questões de letramento escolar, como a aprendizagem de aspectos linguísticos sobre a língua materna, assim como a reflexão de aspectos também importantes, como questões de poder e ideologia presentes na linguagem, a aprendizagem tornou-se significativa porque aplicável na vida social. Essa ressignificação confere maior sentido à prática docente, assim como viabiliza um aprendizado relevante ao aluno.

\section{REFERÊNCIAS}

ANTUNES, I. Muito além da gramática: por um ensino de línguas sem pedras no caminho. São Paulo: Parábola, 2007.

BAKHTIN, M. Os gêneros do discurso. In: BAKHTIN, M. Estética da criação verbal. 4. ed. Tradução de Paulo Bezerra. São Paulo: Martins Fontes, 2003. p. 261-306.

BONINI, A. (Org.). Os gêneros do jornal. Florianópolis: Insular, 2014.

BRASIL. Ministério da Educação e do Desporto. Lei n. ${ }^{0}$ 9.394, de 20 de dezembro de 1996. Estabelece as diretrizes e bases da educação nacional. Diário Oficial da União, Brasília, DF, 23 dez. 1996. Disponível em: < https://bit.ly/1U7QxVu>. Acesso em: 03 jun. 2016.

BRASIL. Ministério da Educação. Secretaria da Educação Fundamental. Parâmetros Curriculares Nacionais: terceiro e quarto ciclos do Ensino Fundamental - Língua Portuguesa. Brasília, 1998. Disponível em: <https://bit.ly/1Rk4QUm>. Acesso em: 03 jun. 2016. 
BRASIL. Diretrizes Curriculares Nacionais para a Educação Básica. In: BRASIL. Ministério da Educação. Diretrizes Curriculares Nacionais Gerais da Educaşão Básica. Ministério da Educação. Secretaria de Educação Básica. Diretoria de Currículos e Educação Integral. Brasília: MEC; SEB; DICEI, 2013. p. 6-79.

ERICKSON, F. Transformation and school success: the politics and culture of educational achievement. Anthropology \& Education Quarterly, v. 18, n. 4, p. 335-356, 1987.

FARACO, C. A. Norma Culta Brasileira: desatando alguns nós. São Paulo: Parábola, 2008.

FREINET, C. O jornal escolar. 2. ed. Lisboa: Estampa, 1974.

GIL, A. C. Como elaborar projetos de pesquisa. 5. ed. São Paulo: Atlas, 2010.

GNERRE, M. Linguagem, escrita e poder. 3. ed. São Paulo: Martins Fontes, 1991.

HERNÁNDEZ, F. Transgressão e mudança na educação: os projetos de trabalho. Tradução de Jussara Haubert Rodrigues. Porto Alegre: ArtMed, 1998.

HERNÁNDEZ, F.; VENTURA, M. A organização do curriculo por projetos de trabalbo: o conhecimento é um caleidoscópio. Tradução de Jussara Haubert Rodrigues. Porto Alegre: ArtMed, 1998.

KLEIMAN, A. Modelos de letramento e as práticas de alfabetização na escola. In: KLEIMAN, A. (Org.). Os significados do letramento: uma nova perspectiva sobre a prática social da escrita. Campinas: Mercado de Letras, 1995. p. 7-61.

KLEIMAN, A. O processo de aculturação pela escrita: ensino da forma ou aprendizagem da função?/ In: KLEIMAN, A.; SIGNORINI, I. (Org.). O ensino e a formação do professor: alfabetização de jovens e adultos. Porto Alegre: Artmed, 2000. p. 223-243.

KLEIMAN, A. Preciso "ensinar" o letramento? Não basta ensinar a ler e a escrever? Campinas: Cefiel; Unicamp, 2005. Disponível em:

$<$ https://bit.ly/2G4xZ81>. Acesso em: 26 jun. 2016.

KLEIMAN, A. Leitura e prática social no desenvolvimento do ensino médio. In: BUNZEN, C.; MENDONÇA, M. (Org.). Português no ensino médio e formação do professor. São Paulo: Parábola, 2006.

KLEIMAN, A. Trajetórias de acesso ao mundo da escrita: relevância das práticas não escolares de letramento para o letramento escolar. Perspectiva, Florianópolis, v. 28, n. 2, p. 375-400, jul./dez. 2010. 
LONDRINA. Secretaria Estadual de Educação. Projeto Politico Pedagógico. Londrina, 2016. Disponível em: <https://bit.ly/2Tx7ICw>. Acesso em: 07 out. 2017.

MARCUSCHI, L. A. Da fala para a escrita: atividades de retextualização. São Paulo: Cortez, 2007.

MARQUES, I. B. de A. S. Formação de professores de Língua Portuguesa: projeto de letramento, agência e empoderamento. In: KLEIMAN, A.; ASSIS, J. A. (Org.). Significados e ressignificaçoes do letramento: desdobramentos de uma perspectiva sociocultural sobre a escrita. São Paulo: Mercado das Letras, 2016. p. 111-143.

OLIVEIRA, M. do S. Gêneros textuais e letramento. Revista Brasileira de Linguística Aplicada, Belo Horizonte, v. 10, n. 2, p. 325-345, 2010 . Disponível em: <https://bit.ly/2L5mADd>. Acesso em: 10 out. 2017.

OLIVEIRA, M. do S.; TINOCO, G. A.; SANTOS, I. B. de A. Projetos de letramento e formação de professores de lingua materna. 2. ed. Natal: EDUFRN, 2014. Disponível em: <https://bit.ly/2GpvPPR>. Acesso em: 25 jan. 2017.

PARANÁ. Secretaria de Estado da Educação. Diretrizes Curriculares da Educação Básica: Língua Portuguesa. Curitiba: SEED, 2008. Disponível em: $<$ https://bit.ly/2MsNiGK>. Acesso em: 05 jun. 2016.

POSSENTI, S. Por que (não) ensinar gramática na escola. Campinas: Mercado de Letras, 1996. SOARES, M. Letramento: um tema em três gêneros. 2. ed. Belo Horizonte: Autêntica, 2001.

STREET, B. Letramentos sociais: abordagens críticas do letramento no desenvolvimento, na etnografia e na educação. Tradução de Marcos Bagno. São Paulo: Parábola, 2014.

STREET, B.; BAGNO, M. Perspectivas interculturais sobre o letramento. Filologia e Linguística Portuguesa, n. 8, p. 465-488, ago. 2006. Disponível em: <https://bit.ly/2D5CWt7>. Acesso em: 13 ago. 2016.

TINOCO, G. M. A. de M. Projetos de letramento: ação e formação de professores de língua materna. 2008. Tese (Doutorado em Estudos da Linguagem) - Universidade Estadual de Campinas, Campinas. Disponível em: < https://bit.ly/2G7bijI>. Acesso em: 20 ago. 2016. 